\title{
VERGIL, PROPERTIUS, AND THE EUPHRATES
}

\section{J Steenkamp (North West University)}

It is now well known that Vergil exploited this twofold nature of the symbol of the Euphrates masterfully. On the one hand he uses it to refer back to Callimachus and in doing so to state his own views on poetry; on the other hand he invokes the famous river of the East to explain how events there impacts on Rome, her new princeps and ultimately his own capacity to write poetry. Propertius, too, was not insensitive to the possibilities afforded by the symbol of the Euphrates and, having Vergil as an example, could exploit the symbol in much the same way as the illustrious poet. This paper is primarily concerned with how Propertius uses the symbol of the Euphrates to speak about his own poetry and the socio-political circumstances in which he wrote.

Delphi and the springs on Parnassus, Helicon and the Capitoline hill before the arrival of Aeneas were important landmarks in the world of the Roman poets of the Augustan Age. Reference to them allowed the poets to discuss, through metaphor and intertext, their world and their poetry. In the same way the river Euphrates constituted an important landmark. The image of the river was used by Callimachus in his famous metaphor (H.2.105-113) about the nature of his own poetry and this programmatic statement became central to Augustan poetics. Politically, the river also marked the boundary between Rome and the Parthian Empire and in the minds of Romans was associated with an exotic enemy and some of the Roman Republic's most bitter defeats.

It is now well known that Vergil exploited this twofold nature of the symbol of the Euphrates masterfully (Scodel \& Thomas 1984:339, Clauss 1988:309-322 and Jenkyns 1993:115-121). On the one hand, he uses it to refer back to Callimachus and in doing so to state his own views on poetry; on the other hand, he invokes the famous river of the East to explain how events there impact on Rome, her new princeps and ultimately his own capacity to write poetry. Propertius, too, was not insensitive to the possibilities afforded by the symbol of the Euphrates and, having Vergil as an example, could exploit the symbol in much the same way as the illustrious poet. This article is primarily concerned with how Propertius uses the symbol of the Euphrates to speak about his own poetry and the socio-political circumstances in which he wrote.

Vergil mentions the river Euphrates only three times and all three instances are placed at very specific geometric points in his poems: in the Georgics at 1.509 and 4.561 and in the Aeneid at 8.726 - all three occurring six lines from the end of a book. This fact on its own might seem like a curious coincidence, but as 
Scodel and Thomas (1984:339) point out, since a reference to the same river is also placed exactly six lines from the end of Callimachus' Hymn to Apollo (1.108), Vergil's architectonic pointers are very significant. In the briefest of notes Scodel \& Thomas comment on the meaning of the Euphrates in Vergil: "At Geo.1.509 the river threatens war; at Geo. 4.561 Octavian thunders there; at A.8.726 the river, after Actium, is no longer threatening".

In a closer look at these particular passages Clauss (1988:309-320) argues that they provide insight not only into Vergil's view on the state of Rome in his own time but also into Vergil's view of his own poetry in relation to Callimachus. Callimachus' views of what constitutes good poetry were crucially important for Augustan poets because they appropriated these views and the metaphor by which he explained them. The introduction to Callimachus' Aetia explains that poetry should not be too heavy or grand and he relates in what has become a famous scene, how, when he first wanted to write poetry, Apollo told him to keep his Muse slender and his sacrificial animal fat, ${ }^{1}$ and that it is better to follow the untrodden paths than to go along the highway. In the Hymn to Apollo (2.105-113) he voices the same sentiment and uses the Euphrates as a symbol to explain this:

Envy secretly whispered in Apollo's ear: "I do not admire the (this) singer, who does not sing as much as the sea". Apollo kicked Envy and said: "The Assyrian river is vast, but it carries with it plenty of mud and much waste on its water. To Demeter, however, bees do not bring every water, but the finest flower of the few droplets that pour forth pure and immaculate from a holy fountain" (trans. Kohnken 1981:411).

Jenkyns (1993:117), however, doubts the nature of the reference to Callimachus. He notes that though "modern scholars tend to suppose that any allusion to Callimachus is an assertion of a particular aesthetic attitude", the Alexandrian poet was also known as a praise poet and that Vergil habitually alluded to him in panegyric passages. Jenkyns feels that Vergil's references to the Euphrates, as they appear in passages praising Octavian rather allude to this aspect of Callimachus' poetry. He also suggests that "the name Euphrates should thrice seem fitting near the close of a great peroration ... must serve some larger purpose than an allusion to the Greek poet, which can be at the most a sort of incidental bonus" (1993:116).

Jenkyns' contention is, however weak in one respect: Callimachus' use of the Euphrates occurs in a passage which explains the core tenet of his aesthetic philosophy and if Vergil recalled the passage when he was composing the

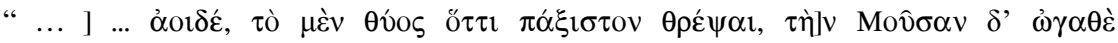
$\lambda \varepsilon \pi \tau \alpha \lambda \varepsilon \dot{\eta} \eta v$. Callim. Aet. 1 fr. 1.23-24 from Thomas 1999:209 ... singer raise your victim to be as fat as possible, but, my good man, your Muse to be slender (trans. Acosta-Hughes \& Stephens 2002:240). 
Georgics - as his exact repetition of the placement of the name indicates - the main point of the Callimachean passage could hardly have escaped him. It seems that such a specific reference by Vergil to such a fundamental expression of Callimachean aesthetics can hardly be reduced to "a sort of incidental bonus" as Jenkyns contends.

In the minds of the Augustan poets, the river Euphrates also existed as a political landmark. It was the eastern limit of the Roman World and one of the great frontiers conquered by Alexander and it was also associated in their own time with the dread of a Parthian invasion. During the latter half of the last century BC three major conflicts occurred there, two of which Rome lost badly. These events impressed themselves deeply in the psyche of the Roman people and were, naturally, treated, examined and analysed in their historiography, art and poetry.

Syria became a Roman Province in 64 BC courtesy of Pompey the Great, following the third Mithridatic war. ${ }^{2}$ Relations between Rome and Parthia were strained at the best of times. In 53 BC Marcus Licinius Crassus, the triumvir, invaded Parthia with an army of no less than 40000 men (according to Plutarch Crass. 20.1), ${ }^{3}$ but lost a decisive battle at Carrhae, in which both he and his son forfeited their lives. In $40 \mathrm{BC}$ a Parthian army under a certain Pacorus (son of Orodes II) and Quintus Labienus (a defector from the Republican faction in Rome) marched on the Roman provinces of Syria and Judea. After some initial successes - they progressed all the way to Jerusalem - they were driven out of Asia Minor by Mark Anthony's generals Pollio and Ventidius in 39 BC. Anthony marched against Parthia in $36 \mathrm{BC}$ with about a 100000 soldiers, but, ill prepared for such a campaign, he was forced to withdraw by the end of the year. From about 32 to 25 BC Parthia suffered internal strife that escalated into civil war. Augustus, by now solidly in power in Rome, took advantage of the circumstances and signed a favourable peace treaty with Phraates (c. 20 BC) who returned the Roman standards lost by Crassus. ${ }^{4}$

First Clauss (1988:309-320) and later Jenkyns (1993:115-121) discussed Vergil's reference to the Euphrates in the context of his Callimachean model and his socio-political environment more fully. Clauss (1988:17-18) believes that Vergil's allusions to the Euphrates and Callimachus serve a twofold purpose: firstly, it serves as an internal reference - i.e. Vergil refers at the end of the third

2 This was the first time Rome shared a border with the (so-called) Parthian Empire - the section of the Euphrates more or less between Zeugma in the north and Nicephorum in the south - Cappadocia and Armenia being client kingdoms at the time.

3 The numbers vary from 30000 to 100000 . For a discussion of the sources see Marshall 1975:143-144 and 173-182.

4 General discussion on the changing relationship between Parthia and Rome can be found in Bowman et al. 1996:158-160. 
Georgics back to the first and at the end of Aeneid 8, back to the end of the Georgics - in order to bring to mind the progression of events involving the river. Secondly, Clauss sees a poetic point in the reference to Callimachus and argues that Vergil refers to his Greek predecessor in the Aeneid, because he wants to "correct" the Callimachean creed, since Octavian has, with his conquests in the East, eradicated the obstacles that prevented him from writing a lengthy, thematically unified poem about a hero. Jenkyns (1993:117-118) objects to the second point in Clauss' argument, as noted above and feels that the political aspect of the allusion to the Euphrates is much more important.

Although critics disagree on certain points, it seems certain that Vergil intended both a poetic and a political statement with his allusion to Callimachus and that the real question is how much of the one, and how little of the other. Before we turn to Propertius' reading of Vergil's Euphrates the relevant texts from the Vergilian corpus will be repeated here in order to facilitate comparison with the Propertian extracts.

The reference to the Euphrates at Georgics 1.509-511 comes after an exposition on inauspicious weather signs.

hinc movet Euphrates, illinc Germania bellum; vicinae ruptis inter se legibus urbes arma ferunt; saevit toto Mars impius orbe (G. $1.509-511)^{6}$

Here the Euphrates and there Germania set war in motion; neighbouring towns, their alliances broken, are under arms - the irreverent Mars rages over the whole world.

The river is threatening war in a world already turned upside down and in which Mars reigns supreme. ${ }^{7}$ Where Callimachus used the river as a symbol of unrestrained verse, Vergil uses it here as a symbol of unrestrained war. It might be added that the mention of rivers from opposite ends of the Roman world implies that this is a global conflict and the use of the adjective impius with Mars suggests that this is not, or, at least, should not be, the natural state of the world. For Vergil, who up to this point has not composed poetry with military themes, the river

5 See Clauss 1988:315 n.25 for a broader explanation of this idea and his criticism of Thomas 1986:182-185), where the term was first applied to Vergil's internal references.

6 The texts of Vergil are those of Mynors published first by Oxford University Press in 1969 and later used in the commentaries by Gransden 1976 and Mynors 1990.

7 Mars also rages at the centre of the depiction of the Battle of Actium on the Shield of Aeneas in Aeneid 8.700-701: saevit medio in certamine Mavors / caelatus ferro [Mars, carved from iron, rages in the middle of the fighting]. 
remains, as it did for Callimachus, a symbol of subjects unsuitable for poetry (Clauss 1988:310-311).

The atmosphere in Georgics 4.561 is much more optimistic: Aristaeus' bees have been resurrected and the death of Eurydice has been expiated.

haec super arvorum cultu pecorumque canebam et super arboribus, Caesar dum magnus ad altum fulminat Euphraten bello victorque volentis per populos dat iura viamque adfectat Olympo. illo Vergilium me tempore dulcis alebat Parthenope studiis florentem ignobilis oti, carmina qui lusi pastorum audaxque iuventa, Tityre, te patulae cecini sub tegmine fagi (G. 4.559-66)

I was singing about these things - crops, the tending of herds and trees - while great Caesar was thundering in war at the deep Euphrates - as victor he gives laws to willing peoples and makes his way to Olympus. At that time sweet Parthenope fed me, Vergil, taking pleasure in ignominious leisure, who with youthful daring played at pastoral songs and sang about you Tityrus, under the cover of a outspread beech.

Now Augustus is thundering at the Euphrates, as victor he is laying down laws and, in doing so, is affording Vergil otium in which to compose pastoral poetry. The same happens to Tityrus in Eclogue 1, the opening line which Vergil refers to in line 566 with a strong verbal echo. More importantly, Clauss (1988:312-313) also sees Vergil making a clear distinction between himself, the poet, who is living a life of luxury in Naples and Octavian, who is fighting in the East. This distinction, as we shall see, is picked up by Propertius in his poems 3.4 and 3.5, where the river Euphrates is also mentioned.

The reference to the Euphrates in the Aeneid (8.726) comes in the final lines of the description of the artwork on the Shield of Aeneas.

ipse sedens niveo candentis limine Phoebi

dona recognoscit populorum aptatque superbis

postibus; incedunt victae longo ordine gentes,

quam variae linguis, habitu tam vestis et armis.

hic Nomadum genus et discinctos Mulciber Afros,

hic Lelegas Carasque sagittiferosque Gelonos

finxerat; Euphrates ibat iam molior undis,

extremique hominum Morini, Rhenusque bicornis,

indomitique Dahae, et pontem indignatus Araxes

(A.8.720-728). 
Caesar himself, sitting on the snow-white threshold of shining Phoebus, recognises the gifts of the peoples and fastens them on the proud doorposts. The conquered nations march in a long procession so varied in language as they are in clothing and arms. Here Mulciber has portrayed the Nomad tribe and there the engirdled Africans, here the Leleges and Carians and the Gelonian archers - the Euphrates now flowing with more restrained waves, the Morini, the most far-off of peoples, the two-horned Rhine and indomitable Dahae and the Araxes that detests its bridge.

Clauss (1988:317-319) gives two reasons for the reference to the river here: (1) It recalls the previous two references and calls to mind the progression of military events: first the river threatens war $(G .1)$, then Octavian thunders there bringing the region under control (G.4) and lastly, the river is, like other rivers, subdued and tamed (A.8). (2) The name of the river recalls Callimachus' statement about poetry and Vergil's restatement of that same credo in Eclogue 6. Clauss' main point is that the river still stands for epic poetry, as it did in Callimachus. But, looking back at Callimachus where the river was an unruly and chaotic source unsuitable for refined poetry, for Vergil the river changed gradually from a threatening force in a world turned upside down to a force restrained by Augustus which flows with humble waves and, tamed, becomes a suitable source for epic poetry. ${ }^{8}$

Propertius mentions the river Euphrates on five occasions - at 2.10.13, 2.23.21, 3.4.4, 3.11.25 and 4.6.84. It would seem reasonable to assume that Propertius would have been aware of Vergil's treatment of the Euphrates when he used the name of the river in his own poetry for at least two reasons: Propertius used Callimachean metaphors to explain his reluctance to compose epic poetry as Vergil had done. Moreover, Propertius did so by using the image of Apollo warning the poet in poem 3.3 in very much the same way Vergil, famously, did at Eclogue 6.3-5, a topos which, in turn, had been adopted from Callimachus' Aetia prologue. Like Vergil, Propertius would also have been intimately aware of the various political undertones connected to the name Euphrates. Although Propertius does not mark his references to the river through special placement like Vergil, his use of the place name suggests that calculated intertextual referencing is at work. Of these five instances in Propertius, three occur in instances where he speaks both about his own poetry and about current political events — they are elegies 2.10 , 3.4 and $4.6 .^{9}$

For a discussion of Vergilian progression (or capitulation), see Thomas 1985:61-73.

The two instances 2.23.21 and 3.11.25 do not refer to political events. In 2.23 the rivers Euphrates and Orontes stand for Mesopotamia and Syria respectively, from which 
In 2.10 Propertius' use of the name Euphrates recalls Georgics 4.561.

iam negat Euphrates equitem post terga tueri

Parthorum et Crassos se tenuisse dolet

India quin, Auguste, tuo dat colla triumpho, et domus intactae te tremit Arabiae

The Euphrates denies the Parthian horsemen protection behind its back $^{11}$ and it pains her that the Crassi were taken. Even India, Augustus, volunteers its neck for your triumph and the untouched house of Arabia trembles before you.

Propertius 2.10 is a recusatio and begins as if the poet is about to write poetry about political subjects, but it soon transpires that he is only promising to write such a poem at some undefined future date and cites his lack of talent as the reason for not doing so immediately. This fact alone already links Propertius' use of the name Euphrates with Vergil through Callimachus, whose opinions about the art of poetry lie behind the Augustan elegists' aversion to epic verse.

The passage is also linked to Georgics 4.561 on another level. The poem begins as a possible start to an epic poem, one the poet refuses to write, but promises to write at a future date under certain political circumstances. By describing these political circumstances, the poet foresees a future where it will be possible to write about political themes in his poetry and, in doing so, he links the political climate to his poetry. Propertius is in fact promising that in a world where the Euphrates no longer actively helps the Parthians, India is capitulating and Arabia is trembling, he will become a follower of the camp of Octavian and be a vates for that camp:

haec ego castra sequar; vates tua castra canendo / magnus ero

This camp (i.e. Octavian's) I will follow, I will be a great vates singing about your camp

(ll. 19-20)

prostitutes come and in 3.11.25 the Euphrates is mentioned as having been diverted to flow through Babylon by Semiramis, one of a number of famous women appearing in the poem.

10 The Propertius extracts in this paper have comparatively few textual problems. The Oxford text is used throughout (Heyworth 2007).

11 Reading post terga with Euphrates presents no problems — rivers are often personified in Propertius, see Camps 1966:110. 
Thus, just as Octavian's thundering at the Euphrates afforded Vergil the otium to write poetry, so the successes of the princeps in the East will provide Propertius with a platform for his own poetry.

Propertius' reference to the Euphrates in 3.4 is also easily linked to Vergil.

arma deus Caesar dites meditatur ad Indos,

et freta gemmiferi findere classe maris.

magna, viri, ${ }^{12}$ merces: parat ultima terra triumphos;

Tigris et Euphrates sub tua iura fluent;

sera, sed Ausoniis veniet provincia virgis;

assuescent Latio Partha tropaea Iovi

The god Caesar is planning war against the wealthy eastern peoples, ${ }^{13}$ and to split the straits of the gem-bearing sea with his fleet. Great, men, are the spoils; the furthest lands are preparing triumphal processions. The Tigris and the Euphrates will flow under your laws, although late, the province will come under the Ausonian standard and the trophies of the Parthian will get used to Latin Jupiter.

Propertius' Tigris et Euphrates sub tua iura fluent echoes the sentiment in Vergil's Euphrates ibat iam molior undis from Aeneid 8.726. ${ }^{14}$ Propertius, foreseeing the Euphrates subdued, is looking forward to a time, which is not dissimilar to the time described by Vergil in the conclusion of the ecphrasis of the Shield of Aeneas. This seems to be the fulfillment of the promise made in 2.10: though Octavian has not yet conquered the East, he is planning to do so and the poet is preparing to become the vates by foreseeing the celebrations that will follow the victories.

However, in the Aeneid the description of the Shield of Aeneas ends with a triumphal procession in the Forum and the suggestion that, once the nations of the world have been subdued, peace will reign and a new Golden Age will commence. In Propertius 3.4 a sinister motive behind Augustus' new conquests - the accumulation of more wealth - is suggested, though not made explicit; the darker side of conquest is revealed. ${ }^{15}$ In this specific poem and its complement 3.5,

12 Some commentators prefer magna, Quiris, merces - for a recent discussion see Heyworth 2007:292.

13 "The Indi here stands for the East in general" as explained by Camps 1966:69.

14 In the light of Propertius 2.34.61-6 it seems fair to assume that by $c$. 23-21 BC a reasonably complete draft of the eighth book of the Aeneid was known by poets in Maecenas' circle. For a discussion of Propertius' position in the circle of Maecenas, see Cairns 2006:295-319.

15 It should be noted that, while Propertius may reserve doubts about the moral justification for making profit through war, he is not necessarily voicing anti-Augustan sentiments. 
Propertius not only praises the military victories of Augustus in the East, but also deplores the excesses of materialism. ${ }^{16}$ While it may seem that Propertius is in favour of Octavian going to war (3.4.1-20) and is even prepared to support him by "singing propitious omens" (3.4.9-10), his patriotic fervour and enthusiasm are undercut by the final couplet of the poem:

praeda sit haec illis, quorum meruere labores: me sat erit Sacra plaudere posse Via

Let these spoils go to them who earned it with their toils; for me it shall be enough to be able to applaud them on the Via Sacra.

This says more than merely that those whose suffering has earned it, may have the plunder and that the poet will be satisfied with applauding them on the Via Sacra. It is laced with a tinge of disillusioned sarcasm, as if the poet is saying that he has no choice but to be satisfied with applauding Augustus, because now, if he wants to write about political themes he can do nothing else but praise the victor. From a programmatic point of view, this picks up on Vergil's Georgics 4.561, where Augustus' thundering in the East created otium for the poet. In Propertius' case, instead of creating opportunity for the poet to write poetry, the conquests in the East have taken from the poet the opportunity to do more than merely praise the victors.

By the time Propertius wrote poem $4.6(c .16 \mathrm{BC})$ a treaty had been signed with the Parthians (c. $20 \mathrm{BC}$ ) and the river had been subdued, so to speak, under Octavian's rule. It is thus easy to take the whole poem as a fulfillment of the promise made by the poet in 2.10 that he will sing about current military events once Octavian controls the East. Poem 3.4 also foresees such a victory in the East and there the poet goes so far as to sing of favourable omens for the battle (3.4.9). But 2.10 is a recusatio and the praise of Octavian in 3.4 is undercut by the poet pertinently distancing himself from the scene in the final lines.

16 The two poems 3.4 and 3.5 "constitute a sort of diptych, a diptych in which the latter poem functions as a logical and thematic complement to the former", Conte 2000:307-310. The opening word of each poem (arma and pacis) clearly marks them as a pair and the poems are indeed mostly about the wars planned by Octavian and peace venerated by lovers like Propertius. Hubbard 1974:81 notes that "war and peace are here considered not as themes for poetry, but as ways of life" and that both poems "see the motive for war as the desire for gain". See also Cairns 2006:344-347. 
Propertius 4.6 has been interpreted in various, often contradictory, ways and it seems best to start this discussion with the text.

ingenium positis irritet Musa poetis:

Bacche, soles Phoebo fertilis esse tuo.

ille paludosos memoret servire Sycambros,

Cepheam hic Meroen fuscaque regna canat,

hic referat sero confessum foedere Parthum:

"reddat signa Remi, mox dabit ipse sua:

sive aliquid pharetris Augustus parcet Eois,

differat in pueros ista tropaea suos.

gaude, Crasse, nigras si quid sapis inter harenas:

ire per Euphraten ad tua busta licet."

Let the Muse stir the mind of recumbent poets: Bacchus, you are used to stirring creativity in your Apollo. ${ }^{17}$ Let this one tell of the slavery of the marsh-dwelling Sycambri, that one sing of the dark-skinned kingdoms of Cephean Meroe, another record how the Parthians lately conceded defeat with a truce. "Let him return the Roman standards, soon he will give up his own: or if Augustus spares the Eastern quivers at all, let him leave those trophies for his grandsons. Crassus, be glad, if you know of it, among the dark dunes: we can cross the Euphrates to your grave".

In all three the instances where Propertius names the Euphrates he explicitly makes the connection between the river and the ignominious military defeat of Crassus at Carrhae. Vergil does not name Crassus or refer to his defeat in connection with the river at all. In all three the instances where Propertius mentions the Euphrates, he also pertinently styles himself as a vates. ${ }^{18}$ In $2.10 .19-20$ he promises to be a vates for Octavian's camp, in 3.1-5 he invokes the persona without actually calling himself a vates and 4.6 starts with the poet referring to himself in sacra facit vates. Vergil refers to himself as vates only once - A.7.41-5 — but crucially at the beginning of the Iliadic second half of the Aeneid, which chronicles military events. Lastly, it is important to note that this specific reference to the Euphrates is not spoken by the poet of 4.6, but put in the mouth of another poet and it is quoted,

17 Taking Bacchus to stand for wine, this line might also be rendered differently: "Wine, you are usually conducive to your Apollo's [art]" or, taking Apollo to stand for poetic technique, "Wine, you, who usually make the poet's craft fertile".

18 For an old, but still relevant discussion of the vates concept in Augustan poetry, see Newman 1967. 
verbatim, at a symposium of poets where the poet of 4.6 seems to be the chairman or at least the arbiter of proceedings.

The references to Crassus and the donning of the vatic persona in Propertius can be explained by the poet's wish to speak about his own poetry and the political events related in it. Though Vergil is not as preoccupied with his own poetics as Propertius is, he is careful to cast himself as a vates when he chronicles the history of Rome in the second half of the Aeneid (7.41-45) and subtly discloses the vatic credentials of the author of the Shield of Aeneas. The events of the battle of Actium in the Aeneid are told by Vulcan, through his artful decoration of the Shield of Aeneas. Casali (2006:186-187) points out that Vulcan, in making the shield, was aware of the vates-poets and their chronicling of future history.

illic res Italas Romanorumque triumphos haud vatum ignarus venturique inscius aevi fecerat ignipotens...

There the Fire-controller delineated the history of Italy and the triumphs of the Romans, not ignorant of the vates nor uninformed of the times to come.

Casali quotes Hardie (1998:97) on the ambiguous meaning of vates: "There is a punning ambiguity which may also be translated as 'poets'; the Shield of Aeneas presents itself as a visual summary of the Latin epic tradition, and of Ennius' Annales in particular. Vulcan knows the future history of Rome - because he has read the poets who will chronicle that history. The authority of the Vergilian text is no more or less than that of the other texts on which it draws, and which it completes". This explains Propertius' donning of the vatic persona in the opening lines of 4.6 and his promise to become a vates in 2.10. Vergil's divine artist was informed by poet-priests just as Vergil himself was informed by no less a poet than Ennius. Hence, Propertius can hardly talk about Octavian's victories or the battle of Actium from any less authoritative a position than that of a fully-fledged vates. Propertius, in writing about Actium, must have been fully aware that he was participating (with Vergil and maybe others) in creating a myth and seems to have felt it necessary to assume a vatic pose to give his version an authoritative ring.

Closely linked to the idea that the vates has the authority to speak about political events and interpret history, is the idea that the vates should instruct people. Horace voices this sentiment in Odes 3.1.1-4 and in the Ars Poetica 391-401 and it is implied in fact that Propertius dons the persona in the opening of the aetiological poem 4.6. Propertius was not satisfied with merely retelling or listing historical events, he wanted to comment on them, give them meaning and 
for Romans this often meant taking exempla from history to show how people should or should not act. This explains why Propertius would link the negative example of Crassus to his references to the Euphrates in every instance. ${ }^{19}$ Propertius' apparent need to instruct his audience also underlies the various mentions of historical and mythical characters in poems 3.4 and 3.5. Donning the vatic persona is also almost indispensable in the context of poem 4.6. Not only is Propertius interpreting recent historical events of national interest, he is also commenting on events that have been treated by Vergil in the Aeneid.

Lastly, it remains to explain why this specific reference to the Euphrates in 4.6 is put in the mouth of another poet. On a programmatic level the fact that Roman military victories and defeats are subjects allowed at the symposium in 4.6 seems to indicate that Propertius, or at least the poet of 4.6, regards these themes as acceptable in poetry, and more specifically, in poetry to which he listens and quotes in his own poetry. But speaking about the Parthian treaty indirectly serves a specific purpose: while the poet would not object to other poets singing about the Parthian and is even prepared to sing about them himself, albeit in an indirect way, he will do so on his own terms.

The terms Propertius imposes on his singing of Roman politics are firstly that it remains elegiac - elegiac in the sense that he will not compose in the hexameters associated with epic verse, which is strongly implied by his own use of elegiac couplets in 4.6 and by the fact that the poet whom he quotes singing about Parthia in lines 79-84 is also using that metre. Stylistically, Propertius remains Callimachean. Pillinger (1969:191-192) gives, from the opening lines of 4.6, several intertextual references to Callimachus and his poetry ${ }^{20}$ and shows (1969:193-199) how much Propertius appropriated from specifically Callimachus' Hymn to Apollo — not only the poet-priest narrator and the structure of the poem, but also the allusions to current political events.

Propertius found himself in a difficult position at the start of the fourth book. He excuses himself from writing about themes of national interest in poems 2.1, 2.10 and 2.34 and in his third book (3.3) he specifically relates how Apollo and Calliope reprimanded him for attempting such poetry. The difficulty of

19 The main ancient sources on the battle of Carrhae - Dio Cassius (40) and Plutarch's Crassus — are adamant that "Crassus' downfall is an obvious example of vé $\mu \varepsilon \sigma i \varsigma$ following on úßpıৎ" (Marshall 1975:147). For the most recent discussion of the battle of Carrhae and insightful observations about how the Romans remembered their military defeats, see Mattern-Parkes 2003:387-396.

20 The lustral water drawn from Cyrene (4.6.4) refers to Callimachus' birthplace; the adjectives mollis and blanda (4.6.5) are associated with the finely crafted poetry Callimachus enjoyed; the ritual purification of the priest with lympha (4.6.7) recalls Propertius' programmatic statement that culminates in 3.3.51 and, lastly, the new road smoothed by the bay leaves (4.6.10) is a typically Callimachean metaphor. 
Propertius' position is that suddenly starting to discuss war and politics in his fourth book would put great strain on the credibility of his poetic persona. It is important to note that Vergil avoided this impasse. When Apollo appears in Eclogue 6.3-5 to the first-person speaker and admonishes him for writing about kings and wars, the god addresses the speaker as the shepherd Tityrus. ${ }^{21}$ In Propertius 3.3, where Apollo also appears to the first-person speaker in the poem, also to criticise the subjects he is choosing for his compositions, the speaker is addressed as "Propertius" (3.3.17). However, to what extent Propertius negotiates this problem by professing that poem 4.6 is in fact an aetiology (4.6.11-12) and by putting the celebratory poetry at the symposium in the mouths of other poets, is debatable.

In conclusion: Propertius' use of the symbol of the Euphrates is, like Vergil's, political, but much more specific. Vergil portrayed fighting in the East only in general and as a mostly positive force as it creates otium for the poet to practise his art. Propertius, by contrast, highlights the negative aspects of war and his references to the Euphrates are linked to the military defeat of Crassus and the hubristic greed that purportedly caused it. Propertius' apparent abhorrence of war - voiced most strongly in 3.4 and 3.5 - is not uncommon in Roman elegy and in this sense he differs markedly from the Vergil of the Aeneid. Thus, by borrowing the symbol of the Euphrates from Vergil and using it in his own pacifistic elegiac poetry, Propertius can add his own commentary on current political affairs through intertextual dialogue with the epic poet.

Though Jenkyns (1993:115-121) disagrees, it seems that Propertius was acutely aware that the Euphrates was also a Callimachean symbol that referred to Alexandrian aesthetics. By incorporating the symbol into poem 4.6, Propertius incorporates the more epic theme of war into elegy, just as poem 4.6 in general incorporates political issues into elegy through the form of the aetiology. However, by putting the reference to the river in the mouth of another poet, Propertius retains the distance between his poetry and poetry about recent Roman historical events, as if granting that these topics may be suitable for elegy, but avoiding them in his own.

\section{BIBLIOGRAPHY}

Acosta-Hughes, B \& Stephens, S A 2002. Rereading Callimachus' 'Aetia' fragment 1. CP 97:238-255.

21 The first to comment on this was Thomas 1999:288-296. His analysis of this narratological aspect of the poem has far-reaching implications. 
Bowman, A K, Champlin, E \& Lintott, A W 1996. The Cambridge Ancient History. Volume 10, The Augustan Empire 43 B.C.-A.D. 69. Cambridge, Cambridge University Press.

Camps, W A 1966. Propertius: Elegies Book 3. Cambridge, Cambridge University Press.

Cairns, F 2006. Sextus Propertius: The Augustan elegist. Cambridge, Cambridge University Press.

Casali, S 2006. The making of the shield: Inspiration and repression in the Aeneid. $G \& R$ 53:185-204.

Clauss, J J 1988. Vergil and the Euphrates revisited. AJP 109:309-320.

Conte, G B 2000. A humorous recusatio: On Propertius 3.5. CQ 50:307-310.

Gransden, K W 1976. Vergil: Aeneid Book 8. Cambridge, Cambridge University Press.

Hardie P 1998. Vergil. Greece and Rome. New Surveys in Classics no. 28 Oxford, Oxford University Press.

Heyworth, S J 2007. Cynthia: A companion to the text of Propertius. Oxford, Oxford University Press.

Hubbard, M 1974. Propertius. London, Duckworth.

Jenkyns, R 1993. Virgil and the Euphrates. AJP 114:115-121.

Kohnken, A 1981. Apollo's retort to Envy's criticism: (Two Questions of Relevance in Callimachus, Hymn 2, 105ff.) AJP 102:411-422.

Marshall, B A 1975. Crassus: A political biography. Amsterdam: Adolf M. Hakkert.

Mattern-Parkes, S P 2003. The defeat of Crassus and the just war. $C W$ 96:387-396.

Mynors, R A B 1990. Vergil: Georgics. Oxford, Clarendon Press.

Newman, J K 1967. The concept of vates in Augustan poetry. Bruxelles, Latomus, Revue d'Études Latines.

Pillinger, H 1969. Some Callimachean influences on Propertius Book 4. HSCP 73:171-199.

Scodel, R S and Thomas, R F 1984. Virgil and the Euphrates. AJP 105:339.

Thomas, R F 1985. From recusatio to commitment: The evolution of the Vergilian programme. In Cairns, F (ed) 1986. Papers of the Liverpool Latin Seminar. Volume 5. Liverpool, F Cairns: 61-73.

Thomas, R F 1986. Virgil's Georgics and the art of reference. HSCP 90:171-198.

Thomas, R F 1999. Reading Virgil and his texts: Studies in intertextuality. Ann Arbor, University of Michigan Press. 